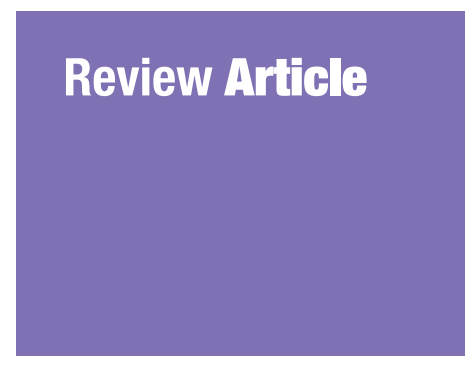

Submitted: 18 Oct 2016

Accepted: 30 May 2017

Online: 26 Oct 2017

\section{A Review of Staphylococcal Cassette Chromosome mec (SCCmec) Types in Coagulase-Negative Staphylococci (CoNS) Species}

\author{
Huda SABER, Azmiza Syawani JASNI, Tengku Zetty Maztura \\ Tengku Jamaluddin, Rosni IBrahim
}

Department of Medical Microbiology and Parasitology, Faculty of Medicine and Health Sciences, Universiti Putra Malaysia, 43400 Serdang, Selangor

Darul Ehsan, Malaysia

To cite this article: Saber H, Jasni AS, Jamaluddin TZMT, Ibrahim R. A review of staphylococcal cassette chromosome mec (SCCmec) types in coagulase-negative staphylococci (CoNS) species. Malays J Med Sci. 2017;24(5):7-18. https://doi.org/10.21315/mjms2017.24.5.2

To link to this article: https://doi.org/10.21315/mjms2017.24.5.2

\begin{abstract}
Coagulase-negative staphylococci (CoNS) are considered low pathogenic organisms. However, they are progressively causing more serious infections with time because they have adapted well to various antibiotics owing to their ability to form biofilms. Few studies have been conducted on CoNS in both, hospital and community-acquired settings, especially in Malaysia. Thus, it is important to study their species and gene distributions. A mobile genetic element, staphylococcal cassette chromosome mec (SCCmec), plays an important role in staphylococci pathogenesis. Among CoNS, SCCmec has been studied less frequently than Staphylococcus aureus (coagulase-positive staphylococci). A recent study (8) conducted in Malaysia successfully detected SCCmec type I to VIII as well as several new combination patterns in CoNS species, particularly Staphylococcus epidermidis. However, data are still limited, and further research is warranted. This paper provides a review on SCCmec types among CoNS species.
\end{abstract}

Keywords: CoNS, epidemiology, SCCmec types, mecA gene

\section{Introduction}

Coagulase-negative staphylococci (CoNS) are catalase-positive gram-positive bacteria that do not possess the ability to clot blood plasma. Categorised under the Micrococcaceae family, CoNS were believed to be less virulent than Staphylococcus aureus (1). However, CoNS have been recently established as one of the major nosocomial pathogens, with Staphylococcus epidermidis and Staphylococcus haemolyticus being identified as the most significant species (2). John et al. (1) stated that CoNS are the most frequent contaminants of blood cultures owing to their normal habitat on the skin. They may also colonise specific areas and cause particular infections; Staphylococcus saprophyticus is responsible for up to $10 \%$ of uncomplicated urinary tract infections in young women; Staphylococcus schleiferi, Staphylococcus lugdunensis, and S. haemolyticus are involved in native valve endocarditis. Newly discovered species such as Staphylococcus pettenkoferi and Staphylococcus nepalensis can also cause human infections; however, this percentage is lower (1). CoNS can produce biofilms; this makes them more resistant to several antibiotics and thereby more difficult to treat than non-biofilm producers $(3,4)$. Biofilm production in CoNS is aided by a molecule called polysaccharide intercellular adhesin (PIA), encoded on ica gene operon, that 
helps in intercellular adhesion (5). In addition to biofilm production, another important characteristic of the CoNS is the staphylococcal cassette chromosome mec (SCCmec), also present in $S$. aureus, the coagulase-positive staphylococci (6). Among other important side elements, SCCmec has the following two important components: the mec gene complex and the $c c r$ gene complex. Till date, although SCCmec types I to XI have been described, only types I to VIII have been established; all these eleven types refer to $S$. aureus as the control strains (7). With respect to CoNS, types I to VIII were successfully detected by using the control types as references (8). The identification of several new types demonstrated the great genetic diversity of SCCmec and the need for developing classification schemes for SCCmec in CoNS (9). This review article covers the following topics:

- The epidemiology and clinical significance of CoNS

- The origin and elements of SCCmec types

- $\quad$ SCCmec types among CoNS species and their clinical significance

- The epidemiological data of SCCmec in CoNS

- Recent findings on new SCCmec types and possible future research

\section{Epidemiology and Clinical Significance of Coagulase-Negative Staphylococci}

More than 40 recognised CoNS species are part of the normal flora of the skin and mucous membranes (10). Species commonly isolated from human infections include $S$. epidermidis, $S$. haemolyticus, and $S$. saprophyticus in addition to other species that are occasionally isolated clinically, such as Staphylococcus hominis, Staphylococcus warneri, Staphylococcus capitis, Staphylococcus simulans, Staphylococcus cohnii, Staphylococcus xylosus, Staphylococcus saccharolyticus, and $S$. lugdunensis (11, 12). CoNS infections are usually associated with indwelling medical devices, especially in very young, old, and immuno-compromised patients since these infectious species are present abundantly on the skin and because of the high frequency of implantation of foreign devices in patients during hospitalisation $(13,14)$. They are recognised as the most frequent cause of prosthetic valve endocarditis, neurosurgical shunt infection, and infection of prosthetic orthopaedic devices because they are able to form biofilms enabling them to adhere to the inert surface of the devices, indirectly promoting increased resistance to antimicrobial agents (15). Moreover, urinary tract infections in young women are also caused by a particular CoNS species, S. saprophyticus (14). However, it was believed that CoNS are contaminants of blood rather than of true CoNS bacteraemia because their natural habitat is the skin. True CoNS bacteraemia and contaminant rates have been reported in bacteraemic patients worldwide. Mert et al. (16) had suggested laboratory criteria for true CoNS bacteraemia that included the assessment of multiple blood cultures positive for the same organisms and growth within 5 days where they found that the true CoNS bacteraemia rate in 249 episodes was $18.1 \%$, consistent with the $6 \%-30 \%$ range as reported in these literatures; Souvenir et al. (17) reported that the prevalence of true CoNS bacteraemia was $24.7 \%$ in a total of 3276 blood cultures from 1433 patients; Finkelstein et al. (18) reported a prevalence of $30 \%$ in 137 episodes in 122 patients; Beekmann et al. (19) screened 960 consecutive patients with positive blood cultures and reported 22\% significant bacteraemia rate. Al-Mazroea (20) concluded that although CoNS are true pathogens, they may act as contaminants in some cases. Therefore, patients with CoNS isolates in the blood cultures should be carefully evaluated before initiating any therapy to prevent the unnecessary use or overuse of antibiotics, especially vancomycin, to prevent the consequent increase in antibiotic resistance in hospitals.

\section{Staphylococcal Cassette Chromosome mec Types}

SCCmec is a mobile genetic element that carries mecA (methicillin-resistant gene) and other functional genes. Zong et al. (9) stated that SCCmec contains the following two essential components: the mec gene complex and the crr gene complex. The mec gene complex consists of mecA, the regulatory genes, and the associated insertion sequences and has been classified into six different classes (A, B, C1, C2, $\mathrm{D}$, and $\mathrm{E}$ ) together with cassette chromosome recombinase (ccr) genes ( $c c r C$ or the pair of ccrA and ccrB) encoding recombinases that mediate the integration and excision of SCCmec into and from the chromosome. In addition, SCCmec also contains few other genes 
such as insertion sequences, transposons, and plasmids (9). Turlej et al. (21) stated that the first SCCmec element was identified in 1999 followed by two additional SCCmec elements (22, 23). Resistance of staphylococci to methicillin and all $\beta$-lactam antibiotics is associated with the presence of the mecA gene that codes for the low affinity of a penicillin-binding protein, PBP2a, which is absent in susceptible staphylococci (24). In other words, the mecA gene is responsible for making staphylococci resistant to penicillin-like antibiotics. Hanssen and Sollid (25) stated in 2006 that till date, the only carrier described for mecA (encoding methicillin-resistance) in staphylococci was SCCmec. According to the International Working Group on the Staphylococcal Cassette Chromosome elements (7), SCCmec types are designated using Roman numerals followed by the $c c r$ and mec gene complex; type I (1B) indicates a SCCmec harbouring a type $1 \mathrm{ccr}$ and a class B mec gene complex. The other established designated SCCmec types are type II (2A), type
III (3A), type IV (2B), type V (5C2), type VI (4B), type VII (5C1), and type VIII (4A), as shown in Figure 1. Till date, eleven SCCmec types (I-XI) and subtypes have been described worldwide in staphylococci, and SCC elements that do not carry mecA (SCC non-mec types) but contain other characteristic genes such as capsule gene cluster, fusidic acid resistance, or the mercuryresistance operon have also been identified in the organisms $(7,26)$. Deurenberg et al. (27) performed molecular identifications of SCCmec type I to VI. Their study results show that types I ( $34.3 \mathrm{~kb})$, IV (20.9 to $24.3 \mathrm{~kb}), \mathrm{V}$ (28 kb), and VI $(20.9 \mathrm{~Kb})$ encode for resistance to $\beta$-lactam antibiotics only. In contrast, SCCmec types II $(53.0 \mathrm{~kb})$ and III $(66.9 \mathrm{~kb})$ possess multiresistance properties because these elements contain additional drug resistance genes carried on integrated plasmids such as pUB110, pI258, and pT181, as well as a transposon (Tn554); plasmid pUB110 codes for kanamycin, tobramycin, and bleomycin resistance; pI258 codes for penicillin and heavy metals resistance;

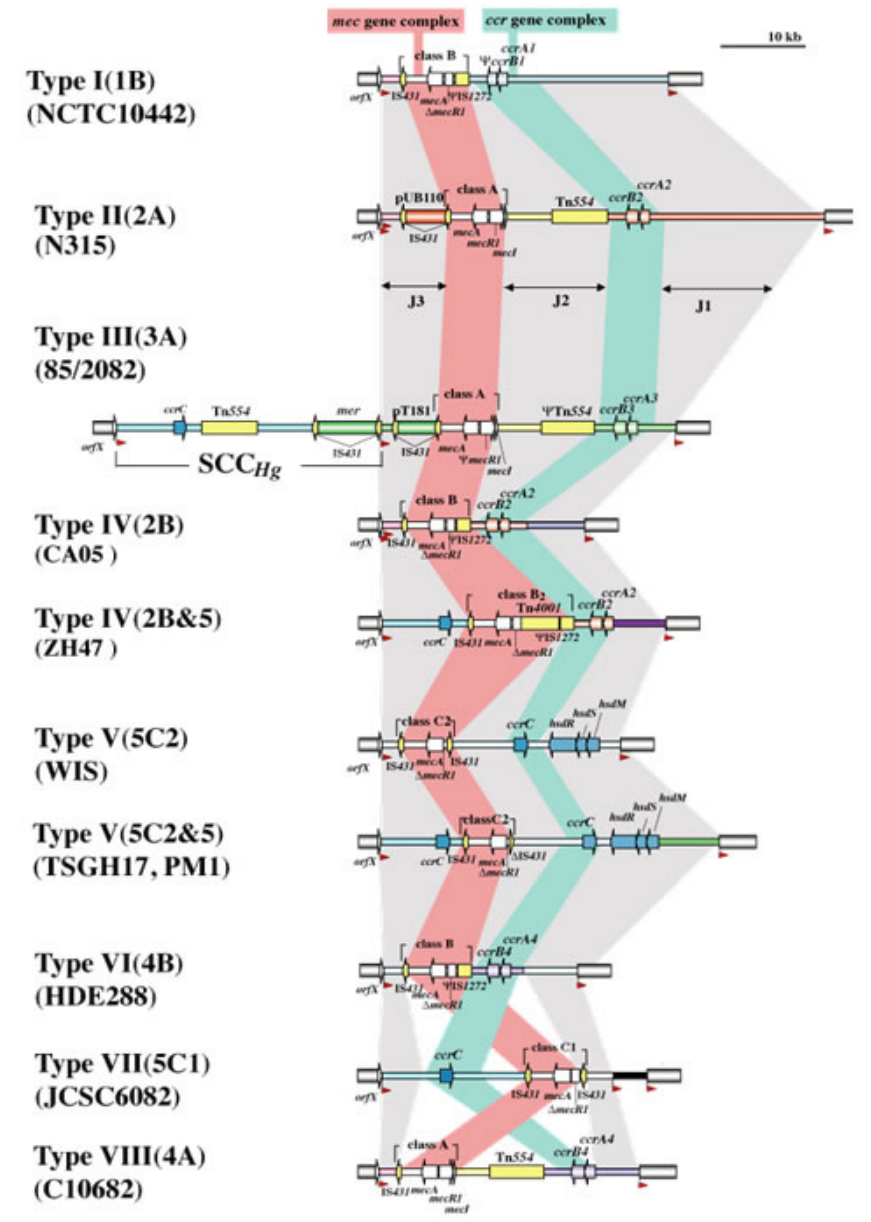

Figure 1. mecA and $c c r$ locations of established SCCmec type I - VIII sequences

Source: Classification of staphylococcal cassette chromosome mec (SCCmec): Guidelines for reporting novel SCCmec elements. Antimicrobial Agents and Chemotherapy. 2009;53(12):4961-4967. 
pT181 codes for tetracycline resistance; and transposon Tn554 (carrying ermA gene) is responsible for inducible macrolide, lincosamide, and streptogramin (MLS) resistance.

\section{Staphylococcal Cassette Chromosome mec Origin}

Tulinski et al. (28) has stated that the origin of SCCmec is still unknown; however, it is believed that the mecA gene itself originated with one common precursor. Homologues of the mecA gene were discovered in Staphylococcus sciuri (29) and Staphylococcus vitulinus (30); however, these homologues are not located in a mecA complex as with SCCmec. Tsubakishita et al. (31) reported that $99 \%-100 \%$ of mecA gene sequence homology was found between Staphylococcus fleurettii and methicillinresistant $S$. aureus (MRSA) strain $\mathrm{N}_{315}$ in addition to the presence of an almost identical structure of the mecA complex that resulted from additional sequence analysis. This shows that a direct precursor of the gene for MRSA is present in $S$. fleurettii, which is categorised under $S$. sciuri within the staphylococci. The possibility that mecA may originate from $S$. fleurettii strengthens the hypothesis that CoNS is the potential reservoir of the SCCmec from which MRSA acquired the elements (25). This is further supported by the fact that methicillin resistance among human clinical isolates is more prevalent in CoNS than in $S$. aureus $(32,33)$. In addition, the observation of an in vivo transfer of SCCmec from $S$. epidermidis to $S$. aureus indicates that CoNS could act as a source for SCCmec acquisition by $S$. aureus (34). Further, $\mathrm{SCCmec}$ types in CoNS are more heterogeneous than those in MRSA, as reported by Hanssen and Sollid (25) and Zhang et al. (35). These findings suggest the possibility of gene transfer in organisms other than staphylococci; therefore, the genes need to be studied in detail to achieve an accurate and adequate understanding of their properties and potential effects.

\section{Staphylococcal Cassette Chromosome mec Types and their Clinical Significance among Coagulase-Negative Staphylococci Species}

CoNS had been recognised as reservoirs of SCCmec based on several evidences of horizontal gene transfers of the SCCmec elements from CoNS to $S$. aureus as well as the diversity of the elements in the CoNS species (36-39). Various types of SCCmec from among ten selected CoNS species isolated from human and animal sources were observed and have been summarised in Table 1. Subtypes under SCCmec types I, II, III, and IV were distributed among $S$. epidermidis, $S$. haemolyticus, $S$. capitis, $S$. sciuri, and $S$. warneri. The three species $S$. epidermidis, $S$. haemolyticus and $S$. capitis had the widest SCCmec distribution with $S$. epidermidis possessing the most types. This is probably because $S$. epidermidis is globally the most commonly found species in hospital and community settings as well as in animal and livestock samples. Some studies could only detect one SCCmec type in one species. This may be because that particular species may have possessed only that particular SCCmec type during the research period. In addition, the SCCmec type distribution may also have been influenced by the type of samples and research locations. From this table, it can be seen that SCCmec types III, IV, and V were the most commonly distributed types among the ten selected CoNS species.

Associated with the potential genetic transfer of resistance elements, CoNS have been commonly identified in hospital-acquired infections whereby some of their SCCmec types have been clinically important, considering their association with antimicrobial resistance and infection risk for patients with indwelling devices, implants, prosthesis, and those subjected to invasive medical procedures (55). As stated by Marchant et al. (56), biofilm formation influences antibiotic resistance and infection persistence in association with central venous catheter (CVC) or other indwelling medical devices despite suitable antibiotic therapy. Zong et al. (9) had found that SCCmec types III, $\mathrm{IV}$, and $\mathrm{V}$ isolated from clinical isolates were resistant to methicillin in addition to other antibiotics. By contrast, in a study done by Singh et al. (57), CoNS isolates with SCCmec types I showed high rates of multidrug resistance. On the other hand, a strong association was observed between SCCmec type I and III and non- $\beta$-lactam antibiotics resistance where the overall resistance was found to be more common in type I isolates, probably due to the higher proportion of those particular isolates than isolates with type III (58). These findings can help in observing the antibiotic resistance 
Review Article | SCCmec types among CoNS species

Table 1. SCCmec types distribution among ten selected CoNS species

\begin{tabular}{|c|c|c|c|}
\hline CoNS species & Source (s) & SCCmec type & Reference \\
\hline S. epidermidis & $\begin{array}{l}\text { Humans, cats, dogs, } \\
\text { horses, pigs, poultry }\end{array}$ & $\begin{array}{l}\text { I, IIa, IIb, III, III (variant), IV, IVa, } \\
\text { IVb, IVc, IVd, IVe, IVg, V, VI, NT }\end{array}$ & $\begin{array}{l}\text { Zhang et al. (35) } \\
\text { Hanssen et al. (40) } \\
\text { Malik et al. (41) } \\
\text { Machado et al. (42) } \\
\text { Jamaluddin et al. (43) } \\
\text { Ruppé et al. (44) } \\
\text { Ibrahem et al. (45) } \\
\text { Garza-González et al. (46) } \\
\text { Vanderhaeghen et al. (47) } \\
\text { Kern \& Perreten (48) } \\
\text { Al-Bakri et al. (49) }\end{array}$ \\
\hline S. haemolyticus & $\begin{array}{l}\text { Humans, cats, } \\
\text { horses, pigs }\end{array}$ & I, II, II.1, III, III (variant), IV, V, NT & $\begin{array}{l}\text { Hanssen et al. (40) } \\
\text { Machado et al. (42) } \\
\text { Ruppé et al. (44) } \\
\text { Ibrahem et al. (45) } \\
\text { Garza-González et al. (46) } \\
\text { Vanderhaeghen et al. (47) } \\
\text { Kern \& Perreten (48) } \\
\text { Al-Bakri et al. (49) } \\
\text { Pi et al. (50) } \\
\text { Hammad et al. (51) }\end{array}$ \\
\hline S. saprophyticus & Humans & III, NT & $\begin{array}{l}\text { Higashide et al. ( } 52) \\
\text { Söderquist \& Berglund } \\
\text { (53) }\end{array}$ \\
\hline S. chromogenes & Humans & IV & Al-Bakri et al. (49) \\
\hline S. hominis & Humans, dogs, pigs & I, III, IV, NT & $\begin{array}{l}\text { Malik et al. (41) } \\
\text { Machado et al. (42) } \\
\text { Ibrahem et al. (45) } \\
\text { Garza-González et al. (46) } \\
\text { Vanderhaeghen et al. (47) } \\
\text { Kern \& Perreten (48) } \\
\text { Al-Bakri et al. (49) }\end{array}$ \\
\hline S. capitis & Humans, dogs & I, IA, II, III, IV, IVa, V, NT & $\begin{array}{l}\text { Machado et al. (42) } \\
\text { Ibrahem et al. (45) } \\
\text { Kern \& Perreten (48) } \\
\text { Al-Bakri et al. (49) }\end{array}$ \\
\hline S. lentus & Cattle, goats, sheep & III & Zhang et al. (35) \\
\hline S. sciuri & $\begin{array}{l}\text { Humans, cattle, } \\
\text { goats, pigs, sheep }\end{array}$ & I, III, IIIA, V, VII, NT & $\begin{array}{l}\text { Zhang et al. (35) } \\
\text { Machado et al. (42) } \\
\text { Vanderhaeghen et al. (47) } \\
\text { Harrison et al. (54) }\end{array}$ \\
\hline S. warneri & $\begin{array}{l}\text { Humans, dogs, } \\
\text { pigs, fish food }\end{array}$ & IV, IV.1, IVb, IVE, NT & $\begin{array}{l}\text { Hanssen et al. (40) } \\
\text { Malik et al. (41) } \\
\text { Vanderhaeghen et al. (47) } \\
\text { Kern \& Perreten (48) } \\
\text { Hammad et al. (51) }\end{array}$ \\
\hline S. cohnii & Humans, dogs & NT & $\begin{array}{l}\text { Kern \& Perreten (48) } \\
\text { Al-Bakri et al. (49) }\end{array}$ \\
\hline
\end{tabular}

NT: Non-typeable 
patterns in CoNS although they may vary between different hospitals. Further molecular approaches are needed to generate more useful data on the molecular epidemiology of nosocomial CoNS isolates (55).

\section{Epidemiological Data of Staphylococcal Cassette Chromosome mec in Coagulase- Negative Staphylococci}

As known, SCCmec elements represent methicillin resistance. Till date, researchers have identified several structural differences in SCCmec elements via SCCmec typing in both, humans and animals. Table 2 summarises the distribution of SCCmec types in CoNS in several representative countries in the western and eastern parts of the world, including Malaysia. In humans, CoNS were isolated from samples such as urine, blood, nasal, and wound. These were also isolated from animals such as dogs, cats, chickens, and cattle.

Almost all SCCmec types have been detected in several western countries with type I being detected most commonly in the following four different countries: Brazil, Finland, Nigeria, and the United States of America (USA), while type VIII was detected most infrequently among the representative western countries. Subtypes of IVb and IVd were also found in Nigeria in addition to the new variants found in Finland and Portugal. A similar pattern was observed in eastern countries where type I was the most commonly distributed, while type VIII was most uncommon. New types such as IIa, IIb, Iva, and IVc were found in Japan; type VII was detected in Iran; and new variants were detected in Malaysia. When we compare the findings in Malaysia to those in the other eastern countries, it was observed that all globally established types (I to VIII) were detected in Malaysia in 2014. Regardless of the SCCmec types in both, the western and eastern regions, human samples were used more than animal samples because
CoNS infection is a greater cause of concern in humans. Table 2 thus shows that till date, SCCmec typing data on animal and livestock samples are limited compared to that on human samples; consequently, typing on animal samples warrants further research in the future. Generally, human-associated CoNS include species such as $S$. epidermidis, $S$. haemolyticus, $S$. hominis, and $S$. capitis with $S$. epidermidis being the most commonly found and studied species, while animal-associated CoNS species include Staphylococcus lentus, Staphylococcus caprae, and Staphylococcus carnosus (2).

Horizontal transfer involving the mecA gene from CoNS to $S$. aureus had been observed. In addition, CoNS are known to be the reservoir of the resistance genes; therefore, the transfer might disseminate pathogenic staphylococci infections such as MRSA throughout the world $(16,34)$. It has been reported that animals infected with CoNS could be reservoirs for human infections through food or direct contact (63), and the horizontal transfer of SCCmec genes among CoNS could also occur between animals (35). However, to the best of our knowledge, gene transfers from animals to humans or vice versa have not yet been well researched and are still under investigation. Further studies on the possible transmission of SCCmec between CoNS from both, animal and human sources are warranted to gain a deeper understanding regarding these transfer mechanisms. Moreover, these findings together with microbial resistance programmes may assist hospitals and perhaps the respective regions to reduce the outbreaks or spread of the pathogenic clonal lineages of the CoNS species (64). In sum, it can be inferred that the variation in the SCCmec types may be influenced by geography, particular situational settings, and sources, and the differences in the data regarding the distribution types across countries are possibly due to the fact that these research studies were unable to detect certain types or intentionally detected only the types of interest. 
Table 2. Distribution of SCCmec types among CoNS isolated from human and animal sources in several countries

\begin{tabular}{cccc} 
Region/Country & Source & SCCmec type & Reference \\
West & & & \\
USA & Animal & I, III, IV, V & Zhang et al. (35) \\
Nigeria & Human & I, IVb, IVd, NT & Vitali et al. (38) \\
Finland & Human & I, II, IV, V, New & Ibrahem et al. (45) \\
Sweden & Human & III, NT & Söderquist and \\
Brazil & Human & Berglund (53) \\
& & I, II, III, IV, (I and III) & Machado et al. (59) \\
Portugal & Human & VI, VIII, NT, New & Bouchami et al. (60) \\
Poland & Human & Vzczuka et al. (61) \\
East & & & \\
Malaysia & Human & I, II, III, IV, V, VI, VIII, NT, New & Sani et al. (8) \\
China & Human & II, III, V & Zong et al. (9) \\
Australia & Animal & I, III, IV, V & Malik et al. (41) \\
Japan & Human & I, IIa, IIb, III, IVa, IVb, IVc, IVd, V, NT & Jamaluddin et al. (43) \\
India & Human & I, II, III, IV, NT & Ghosh et al. (55) \\
Iran & Human & I, II, III, IV, V, VII, NT & Najar et al. (62) \\
& & & \\
\hline
\end{tabular}

NT: Non-typable

\section{Recent Finding on New Staphylococcal Cassette Chromosome mec Type}

In September 2015, Wu et al. (65), reported a novel $c \mathrm{cr}$ gene, $\mathrm{ccrC} 2$, in the SCCmec of $S$. aureus isolate BA01611, which showed $62.6 \%-$ 69.4\% sequence identity to all published $\operatorname{ccrC1}$ sequences. The ccrC2 gene was found to be mainly located among CoNS and could be found in staphylococcal isolates from the USA, France, Germany, and China. Wu et al. (65) categorised the cor gene complex under type 9, while the SCCmec of BA01611 was indicated as a novel type designated as type XII (9C2). This novel SCCmec element in BA01611 was covered by a pseudo

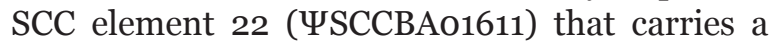
truncated ccrA1. Excision of the SCC elements and a composite SCC from the chromosome was done based on the 24 extra-chromosomal circular intermediates detection. These researchers recommended including the $\mathrm{ccrC2}$ gene and typing $9 \mathrm{ccr}$ gene complexes during the SCCmec typing method revision.

\section{Possible Future Research}

Research on SCCmec in S. aureus may be in its advanced stage; however, the understanding of SCCmec in CoNS is still poor. Data regarding hospital and community-acquired infections were insufficient, especially in Malaysia. This needs to be highlighted since the prevalence and severity of CoNS infections is on the rise. Due to the complex nature and increasing diversity of SCC, more studies need to be conducted, particularly for CoNS, to further investigate the association between the SCCmec types and risk factors, to observe and compare the predominant SCCmec types in samples other than blood, and to identify novel mec genes and allelic variants as well as SCC-encoded virulence-associated genes. These could provide a better understanding of the behavioural aspects of CoNS.

\section{Conclusion}

This paper gives a review of the distribution of SCCmec types among several CoNS species isolated in some countries. CoNS are now as concerning as $S$. aureus in terms of causing serious infections in hospital and community settings; in addition, CoNS are evidenced as the reservoir of SCCmec elements; therefore, their advanced phenotypic and genotypic studies (particularly on SCCmec properties) are crucial for their further characterisation and better understanding. The findings of these can be implemented in the enhancement of infection control, prevention, or the development of new, potential antimicrobial agents, enhancing the 
knowledge, scope, and skills in the fields of science, technology, and medicine.

\section{Acknowledgements}

I wish to express my sincere gratitude to my supervisor, Dr Rosni Ibrahim for always helping and guiding me in writing this review article besides providing financial support of UPM Putra-IPM Grant (grant number 9248100) for my project. Also, thank you very much to my co-supervisors, Dr Azmiza Syawani Jasni and Dr Tengku Zetty Maztura Tengku Jamaluddin for giving advices, ideas and supports. Not forgetting, Assoc Prof Dr Rukman Awang Hamat, other lecturers and lab members for sharing knowledge and experiences in writing this manuscripts.

\section{Authors' Contributions}

Conception and design: HS, RI, ASJ, TZMTJ

Analysis and interpretation of the data: HS

Drafting of the article: HS, RI, ASJ

Critical revision of the article for important intellectual content: HSABS, RI, ASJ, TZMTJ

Final approval of the article: HS

Provision of study materials or patients: RI, ASJ, TZMTJ

Obtaining funding: RI

Collection and assembly of data: HS

\section{Correspondence}

Dr Rosni Ibrahim

Master of Pathology (MPath) (Universiti Kebangsaan Malaysia), Medical Doctor (MD) (University Sains Malaysia)

Department of Medical Microbiology and Parasitology, Faculty of Medicine \& Health Sciences,

Universiti Putra Malaysia,

43400 UPM Serdang,

Selangor Darul Ehsan, Malaysia.

Tel: 0389472363

Fax: 0389413802

E-mail: rosni.ibrahim@upm.edu.my

\section{References}

1. John FJ Jr, Davidson RJ, Low DE. Staphylococcus epidermidis and other coagulase-negative staphylococci. Infectious Disease \& Antimicrobial Agents. 2012. [cited 2016 July 19]. Available from: http://www.antimicrobe.org/new/b234.asp
2. Becker K, Heilmann C, Peters G. Coagulasenegative staphylococci. Clinical Microbiology Reviews. 2014;27(4):870-926. https://doi. org/10.1128/cmr.00109-13

3. El Moufti MF, Baddour M, Harfoush RAH, Owais HMA. Characterization of some genotypic and phenotypic traits of biofilm producing clinical isolates of methicillin resistant staphylococcus epidermidis. American Journal of Infectious Diseases and Microbiology. 2015;3(3):95-103. [cited 2016 Sept 1]. Available from: http://pubs. sciepub.com/ajidm/3/3/2/

4. Agarwal A, Jain A. Association between drug resistance \& production of biofilm in staphylococci. The Indian Journal of Medical Research. 2012;135(4):562. [cited 2016 Apr 22]. Available from: https://www.ncbi.nlm.nih.gov/ pmc/articles/PMC3385245/

5. Wojtyczka RD, Orlewska K, Kępa M, Idzik D, Dziedzic A, Mularz T, et al. Biofilm formation and antimicrobial susceptibility of Staphylococcus epidermidis strains from a hospital environment. International Journal of Environmental Research and Public Health. 2014;11(5):46194633. https://doi.org/10.3390/ijerph110504619

6. Wielders CLC, Fluit AC, Brisse S, Verhoef J, Schmitz FJ. mecA gene is widely disseminated in Staphylococcus aureus population. Journal of Clinical Microbiology. 2002;40(11):39703975. https://doi.org/10.1128/jcm.40.11.39703975.2002

7. Classification of staphylococcal cassette chromosome mec (SCCmec): guidelines for reporting novel SCCmec elements. Antimicrobial Agents and Chemotherapy. 2009;53(12):49614967. https://doi.org/10.1128/aac.00579-09

8. Sani NA, Sapri H, Neoh H-M, Hussin S. First report on the molecular epidemiology of Malaysian Staphylococcus epidermidis isolated from a University Teaching Hospital. BMC Research Notes. 2014;7(1):597. https://doi. org/10.1186/1756-0500-7-597

9. Zong Z, Peng C, Lü X. Diversity of SCCmec elements in methicillin-resistant coagulasenegative staphylococci clinical isolates. PLOS ONE. 2011;6(5):e20191 https://doi.org/10.1371/ journal.pone.0020191 
10. Euzéby JP. List of bacterial names with standing in nomenclature. International Journal of Systematic and Evolutionary Microbiology. 1997;47(2):590-592. [cited 2016 Jan 11]. https:// doi.org/10.1099/00207713-47-2-590

11. Mccann MT, Gilmore BF, Gorman SP. Staphylococcus epidermidis device-related infections: pathogenesis and clinical management. Journal of Pharmacy and Pharmacology. 2008;6o(12):1551-1571. https:// doi.org/10.1211/jpp/60.12.0001

12. Rogers KL, Fey PD, Rupp ME. Coagulase-negative staphylococcal infections. Infectious Disease Clinics of North America. 2009;23(1):73-98. https://doi.org/10.1016/j.idc.2008.10.001

13. Pfaller MA, Herwaldt LA. Laboratory, clinical, and epidemiological aspects of coagulase-negative staphylococci. Clinical Microbiology Reviews. 1988;1(3):281-299. https://doi.org/10.1128/ cmr.1.3.281

14. Brooks GF, Carroll KC, Butel JS, Morse SA. Jawetz, Melnick and Adelbergs. Medical Microbiology. 24th ed. New York: The McGrawHill Companies, Inc.; 2007. 224-232 p.

15. Gill SR, Fouts DE, Archer GL, Mongodin EF, Deboy RT, Ravel J, et al. Insights on evolution of virulence and resistance from the complete genome analysis of an early methicillin-resistant Staphylococcus aureus strain and a biofilmproducing methicillin-resistant staphylococcus epidermidis strain. Journal of Bacteriology. 2005;187(7):2426-2438. https://doi. org/10.1128/jb.187.7.2426-2438.2005

16. Mert G, Kiliç A, Bedir O, Başustaoğlu AC. Clinical significance and staphylococcal cassette chromosome mec (SCCmec) characterization of coagulase-negative staphylococci isolated from blood cultures. Turkish Journal of Medical Sciences. 2011;41(5):859-865. https://doi. org/10.3906/sag-1009-1138

17. Souvenir D, Anderson DE, Palpant S, Mroch $\mathrm{H}$, Askin S, Anderson J, et al. Blood cultures positive for coagulase-negative staphylococci: antisepsis, pseudobacteremia, and therapy of patients. Journal of Clinical Microbiology. 1998;36(7):1923-1926. [cited 2016 Jan 23]. Available from: http://jcm.asm.org/ content/36/7/1923.full
18. Finkelstein R, Fusman R, Oren I, Kassis I, Hashman N. Clinical and epidemiologic significance of coagulase-negative staphylococci bacteremia in a tertiary care university Israeli hospital. American Journal of Infection Control. 2002;30(1):21-25. https://doi.org/10.1067/ mic.2002.118406

19. Beekmann SE, Diekema DJ, Doern GV. Determining the clinical significance of coagulase - negative staphylococci isolated from blood cultures. Infection Control and Hospital Epidemiology. 2005;26(6):559-566. https://doi. org/10.1086/502584

20. Al-Mazroea AH. Incidence and clinical significance of coagulase negative staphylococci in blood. Journal of Taibah University Medical Sciences. 2009;4(2):137-147. https://doi. org/10.1016/s1658-3612(09)70102-7

21. Turlej A, Hryniewicz W, Empel J. Staphylococcal cassette chromosome mec (SCCmec) classification and typing methods: an overview. Pol $J$ Microbiol. 2011;6o(2):95-103. [cited 2016 Jan 20]. Available from: https://www.ncbi.nlm.nih. gov/pubmed/21905625

22. Ito $\mathrm{T}$, Katayama $\mathrm{Y}$, Hiramatsu, K. Cloning and nucleotide sequence determination of the entire mec DNA of pre-methicillin-resistant Staphylococcus aureus N315. Antimicrobial Agents and Chemotherapy. 1999;43(6):14491458. [cited 2016 Feb 14]. Available from: http:// aac.asm.org/content/43/6/1449.short

23. Ito $\mathrm{T}$, Katayama $\mathrm{Y}$, Asada $\mathrm{K}$, Mori $\mathrm{N}$, Tsutsumimoto K, Tiensasitorn C, et al. Structural comparison of three types of staphylococcal cassette chromosome mec integrated in the chromosome in methicillin-resistant Staphylococcus aureus. Antimicrobial Agents and Chemotherapy. 2001;45(5):1323-1336. https://doi.org/10.1128/aac.45·5.1323-1336.2001

24. Petinaki E. Detection of mecA, mecR1 and mecI genes among clinical isolates of methicillinresistant staphylococci by combined polymerase chain reactions. Journal of Antimicrobial Chemotherapy. 2001;47(3):297-304. https:// doi.org/10.1093/jac/47.3.297

25. Hanssen AM, Sollid JUE. SCC mec in staphylococci: genes on the move. FEMS Immunology \& Medical Microbiology. 2006;46(1):8-20. https://doi.org/10.1111/j.1574695x.2005.00009.x 
26. Mongkolrattanothai K, Boyle S, Murphy TV, Daum RS. Novel Non-mecA-containing staphylococcal chromosomal cassette composite island containing pbp4 and tagf genes in a commensal staphylococcal species: a possible reservoir for antibiotic resistance islands in Staphylococcus aureus. Antimicrobial Agents and Chemotherapy. 2004;48(5):1823-1836. https://doi.org/10.1128/aac.48.5.1823-1836.2004

27. Deurenberg R, Vink C, Kalenic S, Friedrich A, Bruggeman C, Stobberingh E. The molecular evolution of methicillin-resistant Staphylococcus aureus. Clinical Microbiology and Infection. 2007;13(3):222-235. https://doi.org/10.1111/ j.1469-0691.2006.01573.x

28. Tulinski P, Fluit AC, Wagenaar JA, Mevius D, Vijver LVD, Duim B. Methicillin-resistant coagulase-negative staphylococci on pig farms as a reservoir of heterogeneous staphylococcal cassette chromosome mec elements. Applied and Environmental Microbiology. 2011;78(2):299304. https://doi.org/10.1128/aem.05594-11

29. Couto I, Lencastre HD, Severina E, Kloos W, Webster JA, Hubner RJ, et al. Ubiquitous Presence of a mecA Homologue in Natural Isolates of Staphylococcus sciuri. Microbial Drug Resistance. 1996;2(4):377-391. https://doi. org/10.1089/mdr.1996.2.377

30. Schnellmann C, Gerber V, Rossano A, Jaquier V, Panchaud Y, Doherr MG, et al. Presence of new mecA and $\mathrm{mph}(\mathrm{C})$ variants conferring antibiotic resistance in staphylococcus spp. isolated from the skin of horses before and after clinic admission. Journal of Clinical Microbiology. 2006;44(12):4444-4454. org/10.1128/jcm.00868-06

31. Tsubakishita S, Kuwahara-Arai K, Sasaki T, Hiramatsu K. Origin and molecular evolution of the determinant of methicillin resistance in staphylococci. Antimicrobial Agents and Chemotherapy. 2010;54(10):4352-4359. https://doi.org/10.1128/aac.00356-10

32. Diekema DJ, Pfaller MA, Schmitz FJ, Smayevsky J, Bell J, Jones RN, et al. Survey of infections due to staphylococcus species: frequency of occurrence and antimicrobial susceptibility of isolates collected in the United States, Canada, Latin America, Europe, and the Western Pacific Region for the SENTRY antimicrobial surveillance program, 1997-1999. Clinical Infectious Diseases. 2001;32(s2). https://doi.org/10.1086/320184
33. Martins A, Cunha MDLR. Methicillin resistance in Staphylococcus aureus and coagulasenegative staphylococci: epidemiological and molecular aspects. Microbiology and Immunology. 2007;51(9):787-795. https://doi. org/10.1111/j.1348-0421.2007.tbo3968.x

34. Wielders C, Vriens M, Brisse S, Graaf-Miltenburg LD, Troelstra A, Fleer A, et al. Evidence for in-vivo transfer of mecA DNA between strains of Staphylococcus aureus. The Lancet. 2001;357(9269):1674-1675. https://doi. org/10.1016/so140-6736(oo)04832-7

35. Zhang Y, Agidi S, Lejeune J. Diversity of staphylococcal cassette chromosome in coagulase-negative staphylococci from animal sources. Journal of Applied Microbiology. 2009;107(4):1375-1383. https://doi.org/10.1111/ j.1365-2672.2009.04322.x

36. Fluit AC, Carpaij N, Majoor EA, Bonten MJ, Willems RJ. Shared reservoir of ccrB gene sequences between coagulase-negative staphylococci and methicillin-resistant Staphylococcus aureus. Journal of Antimicrobial Chemotherapy. 2013;68(8):1707-1713. https:// doi.org/10.1093/jac/dkt121

37. Otto M. Coagulase-negative staphylococci as reservoirs of genes facilitating MRSA infection. Bioessays. 2013;35(1):4-11. https://doi. org/10.1002/bies.201200112

38. Vitali LA, Petrelli D, Lamikanra A, Prenna M, Akinkunmi EO. Diversity of antibiotic resistance genes and staphylococcal cassette chromosome mec elements in faecal isolates of coagulasenegative staphylococci from Nigeria. $B M C$ Microbiology. 2014;14(1):106. https://doi. org/10.1186/1471-2180-14-106

39. Martínez-Meléndez A, Morfín-Otero R, VillarrealTrevino L, González-González G, Llaca-Díaz J, Rodríguez-Noriega E, et al. Staphylococcal cassette chromosome mec (SCCmec) in coagulase negative staphylococci. Medicina Universitaria. 2015;17(69):229-233. https://doi.org/10.1016/j. rmu.2015.10.003

40. Hanssen AM, Kjeldsen G, Sollid JU. Local variants of staphylococcal cassette chromosome mec in sporadic methicillin-resistant Staphylococcus aureus and methicillin-resistant coagulase-negative staphylococci: evidence of horizontal gene transfer? Antimicrobial Agents and Chemotherapy. 2004;48(1):285-296. https://doi.org/10.1128/aac.48.1.285-296.2004 
41. Malik S, Coombs GW, O’brien FG, Peng H, Barton MD. Molecular typing of methicillinresistant staphylococci isolated from cats and dogs. Journal of Antimicrobial Chemotherapy. 2006;58(2):428-431. https://doi.org/10.1093/ $\mathrm{jac} / \mathrm{dkl} 253$

42. Machado ABMP, Reiter KC, Paiva RM, Barth AL. Distribution of staphylococcal cassette chromosome mec (SCCmec) types I, II, III and IV in coagulase-negative staphylococci from patients attending a tertiary hospital in southern Brazil. Journal of Medical Microbiology. 2007;56(10):1328-1333. https://doi. org/10.1099/jmm.0.47294-O

43. Jamaluddin TZMT, Kuwahara-Arai K, Hisata K, Terasawa M, Cui L, Baba T, et al. Extreme genetic diversity of methicillin-resistant staphylococcus epidermidis strains disseminated among healthy Japanese children. Journal of Clinical Microbiology. 2008;46(11):3778-3783. https:// doi.org/10.1128/jcm.02262-07

44. Ruppé E, Barbier F, Mesli Y, Maiga A, Cojocaru $\mathrm{R}$, Benkhalfat M, et al. Diversity of staphylococcal cassette chromosome mec structures in methicillin-resistant Staphylococcus epidermidis and Staphylococcus haemolyticus strains among outpatients from four countries. Antimicrobial agents and chemotherapy. 2009;53(2):442-449. https://doi.org/10.1128/aac.00724-08

45. Ibrahem S, Salmenlinna S, Virolainen A, Kerttula AM, Lyytikäinen $\mathrm{O}$, Jägerroos $\mathrm{H}$, et al. Carriage of methicillin-resistant staphylococci and their SCCmec types in a long-term-care facility. Journal of Clinical Microbiology. 2009;47(1):32-37. https://doi.org/10.1128/ jcm.01085-08

46. Garza-Gonzālez E, Morfin-Otero R, Llaca-Diaz JM, Rodriguez-Noriega E. Staphylococcal cassette chromosome mec (SCC mec) in methicillinresistant coagulase-negative staphylococci. A review and the experience in a tertiarycare setting. Epidemiology and Infection. 2010;138(05):645-654. https://doi.org/10.1017/ s0950268809991361

47. Vanderhaeghen W, Vandendriessche S, Crombé F, Dispas M, Denis O, Hermans K, et al. Species and staphylococcal cassette chromosome mec (SCCmec) diversity among methicillin-resistant non-Staphylococcus aureus staphylococci isolated from pigs. Veterinary Microbiology.
2012;158(1):123-128. https://doi.org/10.1016/j. vetmic.2012.01.020

48. Kern A, Perreten V. Clinical and molecular features of methicillin-resistant, coagulasenegative staphylococci of pets and horses. Journal of Antimicrobial Chemotherapy. 2013;68(6):1256-1266. https://doi.org/10.1093/ jac/dkto2o

49. Al-Bakri AG, Al-Hadithi H, Kasabri V, Othman G, Kriegeskorte A, Becker K. The epidemiology and molecular characterization of methicillinresistant staphylococci sampled from a healthy Jordanian population. Epidemiology and Infection. 2013;141(11):2384-2391 https://doi. org/10.1017/so950268813000010

50. Pi B, Yu M, Chen Y, Yu Y, Li L. Distribution of the ACME-arcA gene among meticillin-resistant Staphylococcus haemolyticus and identification of a novel ccr allotype in ACME-arcA-positive isolates. Journal of Medical Microbiology. 2009;58(6):731-736. https://doi.org/10.1099/ jmm.0.007351-0

51. Hammad AM, Watanabe W, Fujii T, Shimamoto T. Occurrence and characteristics of methicillinresistant and-susceptible Staphylococcus aureus and methicillin-resistant coagulase-negative staphylococci from Japanese retail ready-toeat raw fish. International Journal of Food Microbiology. 2012;156(3):286-289. https:// doi.org/10.1016/j.ijfoodmicro.2012.03.022

52. Higashide M, Kuroda M, Omura CT, Kumano M, Ohkawa S, Ichimura S, et al. Methicillinresistant Staphylococcus saprophyticus isolates carrying staphylococcal cassette chromosome mec have emerged in urogenital tract infections. Antimicrobial Agents and Chemotherapy. 2008;52(6):2061-2068. https://doi. org/10.1128/aac.01150-07

53. Söderquist B, Berglund C. Methicillinresistant Staphylococcus saprophyticus in Sweden carries various types of staphylococcal cassette chromosome mec (SCCmec). Clinical Microbiology and Infection. 2009;15(12):11761178. https://doi.org/10.1111/j.1469-0691.2009. 02771.x

54. Harrison EM, Paterson GK, Holden MT, Ba X, Rolo J, Morgan FJ, et al. A novel hybrid SCCmecmecC region in Staphylococcus sciuri. Journal of Antimicrobial Chemotherapy. 2014;69(4):911918. https://doi.org/10.1093/jac/dkt452 
55. Ghosh A, Singh Y, Kapil A, Dhawan B. Staphylococcal Cassette Chromosome mec (SCCmec) typing of clinical isolates of coagulasenegative staphylocci (CoNS) from a tertiary care hospital in New Delhi, India. The Indian Journal of Medical Research. 2016;143(3):365. https:// doi.org/10.4103/0971-5916.182629

56. Marchant EA, Boyce GK, Sadarangani M, Lavoie PM. Neonatal sepsis due to coagulasenegative staphylococci. Clinical and Developmental Immunology. 2013; Article ID 586076:10 p. [cited 2016 Aug 14]. https:// doi.org/10.1155/2013/586076. Available from: https://www.hindawi.com/journals/ jir/2013/586076/

57. Singh S, Dhawan B, Kapil A, Kabra SK, Suri A, Sreenivas V, et al. Coagulase-negative staphylococci causing blood stream infection at an Indian tertiary care hospital: prevalence, antimicrobial resistance and molecular characterisation. Indian Journal of Medical Microbiology. 2016;34(4):500. https://doi. org/10.4103/0255-0857.195374

58. Murugesan S, Perumal N, Mahalingam SP, Dilliappan SK, Krishnan P. Analysis of antibiotic resistance genes and its associated SCCmec types among nasal carriage of methicillin resistant coagulase negative staphylococci from community settings, Chennai, Southern India. Journal of Clinical and Diagnostic Research. 2015;9(8):DCo1-5. https://doi.org/10.7860/ jcdr/2015/11733.6307

59. Machado ABMP, Reiter KC, Paiva RM, Barth AL. Distribution of staphylococcal cassette chromosome mec (SCCmec) types I, II, III and IV in coagulase-negative staphylococci from patients attending a tertiary hospital in southern Brazil. Journal of Medical Microbiology. 2007;56(10):1328-1333. https://doi. org/10.1099/jmm.0.47294-0

60. Bouchami O, Hassen AB, De Lencastre $\mathrm{H}$, Miragaia M. Molecular epidemiology of methicillin-resistant Staphylococcus hominis (MRSHo): low clonality and reservoirs of SCCmec structural elements. PloS One. 2011;6(7):e21940. https://doi.org/10.1371/journal.pone.0021940
61. Szczuka E, Krajewska M, Lijewska D, Bosacka K, Kaznowski A. Diversity of staphylococcal cassette chromosome mec elements in nosocomial multiresistant Staphylococcus haemolyticus isolates. Journal of Applied Genetics. 2016;57(4):543-547. https://doi.org/10.1007/ s13353-016-0346-5

62. Najar Peerayeh S, Moghaddas AJ, Bakhshi B, Ghasemian A. Diversity of the SCCmec types among Staphylococcus epidermidis clinical isolates from intensive care unit patients. Asian Pacific Journal of Tropical Disease. 2016;6(2):133-135. https://doi.org/10.1016/ s2222-1808(15)60998-7

63. Park YK, Paik YH, Yoon JW, Fox LK, Hwang SY, Park YH. Dissimilarity of ccrAB gene sequences between methicillin-resistant Staphylococcus epidermidis and methicillinresistant Staphylococcus aureus among bovine isolates in Korea. Journal of Veterinary Science. 2013;14(3):299-305. https://doi.org/10.4142/ jvs.2013.14.3.299

64. Ferreira CM, Naveca FG, Ferreira WA, Oliveira $\mathrm{CM}$, Barbosa MD. Novel methicillin-resistant coagulase-negative Staphylococcus clone isolated from patients with haematological diseases at the Blood Bank Centre of Amazon, Brazil. Memórias do Instituto Oswaldo Cruz. 2013;108(2):233$238 . \quad$ https://doi.org/10.1590/00740276108022013017

65. Wu Z, Li F, Liu D, Xue H, Zhao X. Novel type XII staphylococcal cassette chromosome mec harboring a new cassette chromosome recombinase, CcrC2. Antimicrobial Agents and Chemotherapy Antimicrob. 2015;59(12):75977601. https://doi.org/10.1128/aac.01692-15 